\title{
Detection of mutagenic activity of Lake Sevan water using Trad-SHM and Trad- MCN bioassays
}

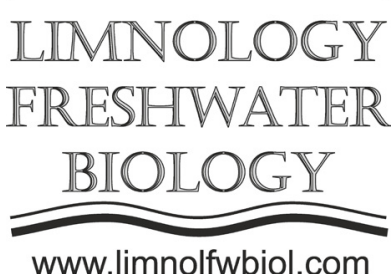

\author{
Avalyan R.E., Aghajanyan E.A., Atoyants A.L., Aroutiounyan R.M. \\ Laboratory of General and Molecular Genetics, RI “Biology”, Yerevan State University, Charents Str., 8 Yerevan, 0025, Armenia
}

\begin{abstract}
The process of bioindication of freshwater ecosystems mutagenic effects using sensitive test-objects of plants is very appropriate and effective. We have investigated the genotoxicity and clastogenicity of deep water samples $(2-4 \mathrm{~m}$ ) in seven locations of Lake Sevan basin (Armenia) with the application of Trad-SHM (staimen hair mutation) and Trad-MCN (micronuclei in tetrads of microspores) bioassays using Tradescantia (clone 02). The study has revealed a significant increase in the frequency of somatic resessive mutation (RME) and increased amount of micronuclei in tetrads and tetrads with micronuclei in microspores of the plants submerged in the all studied water samples compared to the background. The significant positive correlation between the RME frequency and the concentration of some chemical elements - Ni, Mo, Fe, $\mathrm{Ca}, \mathrm{Mg}, \mathrm{K}, \mathrm{Na}$ in the studied water samples was shown. Also the positive correlation between tetrads with micronuclei frequency and the concentration of $\mathrm{Cd}, \mathrm{Ni}, \mathrm{Mo}$, $\mathrm{Fe}, \mathrm{Ca}, \mathrm{Mg}, \mathrm{Na}$ in the investigated water samples was shown.
\end{abstract}

Keywords: Tradescantia (clone 02), deep water pollution, freshwater ecosystem, biotesting, genotoxic and clastogenic effects

Plant bioassays are more sensitive than most of the other test-systems to detect the mutagenic effects of environmental pollutans. For the last years in Armenia fresh water resources (Lake Sevan) have been affected by anthropogenic impact. The process of bioindication of genotoxic effects of complex mixtures on the water environment using higher plants is very appropriate and effective (Majer et al., 2005). Clone 02 Tradescantia is a natural hybrid between Tradescantia occidentalis Briffon ex Ridb. and T. ohiensis Raf. This clone is heterozygous for flower color (blue - dominant, pink - recessive). The Tradescantia stamen hair mutation (Trad-SHM) and Tradescantia-micronucleus (Trad-MCN) bioassays are both the efficient and reliable biomonitory test-systems for detection of the genotoxicity and clastogenicity of air, water and soil pollutants. This assays have been included by the International Program on Plant Bioassay (IPPB) under the auspies of the United Nations Environment Programme (UNEP).

During the Trad-SHM assay the following changes have been considered as indicator test-criteria of genotoxicity: change of the stamen hair cells color from blue to pink (recessive mutation events - RME) and appearance of white cells (undefined white mutation events - WME). The Trad-MCN assay, using chromosomes damage as the indicator of the clastogenic effects of environmental agents, is an efficient tool for screening of water pollutants. The following test-criteria were taken into account: the number of micronuclei per 100 tetrads and the number of tetrads with micronuclei. Micronucleus frequencies were determined in early tetrads of pollen mother cells and expressed as MCN/100 tetrads.

Lake Sevan is the main freshwater source of Armenia, contains $80 \%$ of water resources and plays an important role in regulating the water balance and economic development of the country.

The aim of our study was to test the genotoxicity and clastogenicity of deep water from different parts of the Lake Sevan basin using Trad-SHM and Trad-MCN bioassays of model test-object Tradescantia (clone 02).

Water samples were collected from seven locations of the Lake Sevan basin: off the D-model point, Gavaraget, Shorzha, Tsapatakh, Arpa, Noradus, and Gilly. The water samples were collected at a depth of approximately 2-4 meters. Tap water was used as a background (control). Studied water samples were analyzed for their chemical composition. The quantification of mutation events and the scoring of the micronuclei were carried out as described by standard protocols (Ma et al., 1994a; 1994b). Statistical analysis was carried out with application of the computer program Statgraphics Centurion 16.2.

We conducted a biotesting of the level of genotoxicity and clastogenicity of the deep waters of Lake Sevan basin (Armenia) using two test systems of 
Table. Induction of genotoxic and clastogenic effects of Tradescantia (clone 02)

\begin{tabular}{|l|c|c|c|}
\hline \multirow{2}{*}{ Water Sampling sites } & \multirow{2}{*}{$\begin{array}{c}\text { Frequency } \\
\text { of RME/ 1000 }\end{array}$} & $\begin{array}{c}\text { Frequency of Micronuclei (MN)/100 } \\
\text { (\% } \pm \text { SD) }\end{array}$ & $\begin{array}{c}\text { MCN in tetrads } \\
\pm \text { SD) }\end{array}$ \\
\hline 1. D-model point & $0.98 \pm 0.31^{* * *}$ & $3.7 \pm 0.34^{* * *}$ & $4.4 \pm 0.37^{* * *}$ \\
2. Gavaraget & $0.68 \pm 0.22^{* *}$ & $4.0 \pm 0.36^{* * *}$ & $4.6 \pm 0.37^{* * *}$ \\
3. Shorzha & $1.1 \pm 0.22^{* * *}$ & $6.1 \pm 0.43^{* * *}$ & $7.6 \pm 0.48^{* * *}$ \\
4. Tsapatakh & $1.5 \pm 0.36^{* * *}$ & $8.7 \pm 0.51^{* * *}$ & $10.8 \pm 0.56^{* * *}$ \\
5. Arpa & $1.5 \pm 0.26^{* * *}$ & $8.4 \pm 0.50^{* * *}$ & $11.4 \pm 0.58^{* * *}$ \\
6. Noradus & $1.5 \pm 0.26^{* * *}$ & $4.3 \pm 0.37^{* * *}$ & $5.9 \pm 0.43^{* * *}$ \\
7. Gilly & $2.1 \pm 0.30^{* * *}$ & $5.2 \pm 0.40^{* * *}$ & $6.4 \pm 0.44^{* * *}$ \\
Background & $0.4 \pm 0.19$ & $2.2 \pm 0.27$ & $2.7 \pm 0.29$ \\
\hline
\end{tabular}

$* \mathrm{p}<0.05, * * \mathrm{*}-\mathrm{p}<0.01, * * *-\mathrm{p}<0.001$

the Tradescantia (clone 02) model test object (Table). According to the bioassay of stamen hair mutation (Trad-SHM), a significant increase in the level of pink mutational events (RME), white mutational events (WME), as well as non-surviving hairs (SH) in all studied water samples was shown as compared with the background. The maximum manifestation of the RME level was observed in the Gilly water sampling point, which exceeded the control level by 5 times. A high level of WME and $\mathrm{SH}$ was recorded in the Tsapatakh sampling point, where the values of the studied parameters were 5.5 and 11.5 times higher than the control. We showed the significant positive correlation between the level of RME and the chemical components - $\mathrm{Ni}, \mathrm{Mo}, \mathrm{Fe}, \mathrm{Ca}, \mathrm{Mg}, \mathrm{K}, \mathrm{Na}$; the level of $\mathrm{WME}$ and the concentration of $\mathrm{Cd}, \mathrm{Mo}, \mathrm{Fe}, \mathrm{Ca}, \mathrm{Mg}, \mathrm{K}, \mathrm{Na}$, and also between the $\mathrm{SH}$ values and the concentration of $\mathrm{Cd}$, Co in the studied water samples. A similar increase in the level of genetic effects was also observed according to the micronuclear assay (Trad-MCN) when studying its two main test criteria: the percentage of tetrads with micronuclei and micronuclei in tetrads. The highest degree of occurrence of micronuclei and tetrads with micronuclei in sporogenous cells of the Tradescantia was manifested in the water variants Arpa and Tsapatakh. According to the correlation analysis by the micronuclear assay it was shown the significant positive correlation between both test criteria and the concentration of chemical components - Cd, Ni, Mo, Fe, $\mathrm{Ca}, \mathrm{Mg}$, Na.

The use of both bioassays (Trad-SHM) and Trad-MCN) of model test-object Tradescantia (clone 02) may be effective for biotesting the deep water quality and can allow assessing the potential risk of aquatic contaminants of the freshwater hydroecosystem of Lake Sevan.

\section{References}

Majer B.J., Grummi T., Uhl M. et al. 2005. Use of plant bioassay for the detection of genotoxins in the aquatic environment. Acta Hydrochimical Hydrobiology 33: 45-55. DOI: S1383-5718(02)00004-9

Ma T.H., Cabrera G.L., Cebulska-Wasilevska A. et al. 1994a. Tradescantia stamen hair mutation bioassay. Mutation Research 310: 211-220. DOI: 0027-5107/94// S07.00

Ma T.H., Cabrera G.L., Chen R. et al. 1994b. Tradescantia micronucleus bioassay. Mutation Research 310: 220-230. DOI: 0027-5107/94//S07.00 